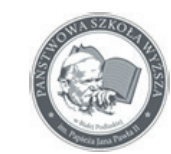

Authors' contribution/

Wkład autorów:

A. Zaplanowanie badań/

Study design

B. Zebranie danych/

Data collection

C. Analiza statystyczna/

Statistical analysis

D. Interpretacja danych/

Data interpretation

E. Przygotowanie tekstu/

Manuscript preparation

F. Opracowanie

piśmiennictwa/

Literature search

G. Pozyskanie funduszy/

Funds collection
ISSN 2083-3725

Volume 10, No. 2, 2017

\section{REPORT FROM THE NATIONWIDE POLISH SCIENTIFIC CONFERENCE “BORDERLANDS IN THE PERSPECTIVE OF THE PRESENT-DAY CHALLENGES", ROSKOSZ, 19-20 APRIL 2017}

\section{SPRAWOZDANIE Z OGÓLNOPOLSKIEJ KONFERENCJI NAUKOWEJ „POGRANICZA W PERSPEKTYWIE WYZWAŃ WSPÓŁCZESNOŚCI”, ROSKOSZ, 19-20 KWIETNIA 2017 R.}

\author{
Dawid Błaszczak, Izabela Jaroszewska
}

\author{
Pope John Paul II State School of Higher Education in Biała Podlaska \\ Państwowa Szkoła Wyższa im. Papieża Jana Pawła II w Białej Podlaskiej
}

Błaszczak D., Jaroszewska I. (2017), Report from the Nationwide Polish Scientific Conference "Borderlands in the perspective of the present-day challenges", Roskosz, 19-20 April 2017/Sprawozdanie z Ogólnopolskiej Konferencji Naukowej „Pogranicza w perspektywie wyzwań współczesności”, Roskosz, 19-20 kwietnia 2017 r. Economic and Regional Studies, Vol. 10, No. 2, pp. 107-111. https://doi.org/10.2478/ers-2017-0019
On 19-20 April 2017, the Department of Sociology hosted a conference entitled "Borderlands in the Perspective of the Present-Day Challenges" (org. "Pogranicza w perspektywie wyzwań współczesności") at the Manor-Park Complex in Roskosz. The Centre for Regional and Borderland Studies of the University of Wrocław was a conference partner. The patronage over the conference was assumed by the Polish Sociological Association, Euroregion Bug Local Governments Association, the County Office in Biała Podlaska and the Office of Biała Podlaska Municipality. The Scientific Committee of the Conference was composed of: prof. Slawomir Partycki PhD Eng. - chairperson, Pope John Paul II State School of Higher Education in Biała Podlaska, The John Paul II Catholic University of Lublin, prof. Zbigniew Kurcz - Vice-Chairman, University of Wroclaw, prof. Leszek Gołdyka - University of Zielona Góra, prof. Irena Machaj - University of Szczecin, prof. Andrzej Sadowski - University of Bialystok, prof. Elena Wankiewicz - State University of Technology in Witebsk, Associate Prof. Adam Bobryk - University of Natural Sciences and Humanities in Siedlce, Associate Prof. Stefan Durda - University of Zielona Góra, Associate Prof Tadeusz Popławski - State Higher School of Informatics and Entrepreneurship in Łomża, Associate Professor Adam A. Szafrański Pope John Paul II State School of Higher Education in Biała Podlaska, Pope John Paul II Catholic University of Lublin, prof. Julita Makaro - University of Wrocław, Elżbieta Opiłowska PhD - University of Wrocław.
W dniach 19-20 kwietnia 2017 roku w Zespole Dworsko-Parkowym w Roskoszy odbyła się organizowana przez Zakład Socjologii Ogólnopolska Konferencja pt., „Pogranicza w perspektywie wyzwań współczesności". Partnerem spotkania był Ośrodek Badań Regionalnych i Obszarów Pogranicza Uniwersytetu Wrocławskiego. Patronat nad konferencja objęło Polskie Towarzystwo Socjologiczne, Stowarzyszenie Samorządów Euroregionu Bug, Starostwo Powiatowe w Białej Podlaskiej oraz Urząd Gminy Biała Podlaska. W komitecie naukowym konferencji zasiadali: prof. zw. dr hab. inż. Sławomir Partycki - Przewodniczący, Państwowa Szkoła Wyższa im. Papieża Jana Pawła II w Białej Podlaskiej, Katolicki Uniwersytet Lubelski Jana Pawła II, prof. zw. dr hab. Zbigniew Kurcz - Wiceprzewodniczący, Uniwersytet Wrocławski, prof. zw. dr hab. Leszek Gołdyka - Uniwersytet Zielonogórski, prof. zw. dr hab. Irena Machaj - Uniwersytet Szczeciński, prof. zw. dr hab. Andrzej Sadowski - Uniwersytet w Białymstoku, prof. dr hab. Elena Wankiewicz - Witebski Państwowy Uniwersytet Technologiczny, prof. nadzw. dr hab. Adam Bobryk - Uniwersytet Przyrodniczo-Humanistyczny w Siedlcach, prof. nadzw. dr hab. Stefan Durda - Uniwersytet Zielonogórski, prof. nadzw. dr hab. Tadeusz Popławski - Państwowa Wyższa Szkoła Informatyki i Przedsiębiorczości w Łomży, prof. nadzw. dr hab. Adam A. Szafrański - Państwowa Szkoła Wyższa im. Papieża Jana Pawła II w Białej Podlaskiej Katolicki Uniwersytet Lubelski Jana Pawła II, dr hab. Julita Makaro - Uniwersytet Wrocławski, dr Elżbieta Opiłowska - Uniwersytet Wrocławski.

Address for correspondence/ Adres korespondencyjny: dr Dawid Błaszczak, mgr Izabela Jaroszewska, Państwowa Szkoła Wyższa im. Papieża Jana Pawła II w Białej Podlaskiej, Wydział Nauk o Zdrowiu i Nauk Społecznych, ul. Sidorska 95/97, 21-500 Biała Podlaska, Polska; tel. +48 83 344 99 11; e-mail: dawid-blaszczak@wp.pl

Journal indexed in/ Czasopismo indeksowane w: AgEcon Search, AGRO, BazEkon, Index Copernicus Journal Master List, ICV 2015: 81,26; Polish Ministry of Science and Higher Education 2016: 9 points/ AgEcon Search, AGRO, BazEkon, Index Copernicus Journal Master List ICV 2015: 81,26; Ministerstwie Nauki i Szkolnictwa Wyższego 2016: 9 punktów. Copyright: (C) 2017 Pope John Paul II State School of Higher Education in Biała Podlaska, Dawid Błaszczak, Izabela Jaroszewska. All articles are distributed under the terms of the Creative Commons Attribution-NonCommercial-ShareAlike 4.0 International (CC BY-NC-SA 4.0) License (http://creativecommons.org/licenses/bync-sa/4.0/), allowing third parties to copy and redistribute the material in any medium or format and to remix, transform, and build upon the material, provided the original work is properly cited and states its license. 
The conference included two days of plenary sessions. The first day of the session began with an official opening. Before the commencement of the conference proceedings, Joanna Marchel PhD, ViceDean of the Faculty of Health and Social Sciences, took the floor. She officially introduced the guests and made reference to the history of the venue, the ManorPark Complex in Roskosz. She emphasized that to her great pleasure so many participants arrived from various parts of the country. During the next part of the meeting, prof. Slawomir Partycki PhD Eng., the chairman of the Scientific Committee, emphasized the unique nature of the meeting and pointed to the need for further exploration of issues associated with borderland areas. He explained that the borderland, i.e. Biała Podlaska District and the city of Biała Podlaska occupies a special place because it is also the borderland of the European Union, and therefore additional duties are imposed on it. For this reason, it must be able to cooperate with the neighbours from Belarus and Ukraine and as a such region it has specific tasks to measure up to. The borderland area consists primarily of Biała Podlaska County. District Offices Janusz Skolimowski, Deputy Staroste (District Governor) spoke on behalf of Biała Podlaska Staroste. He addressed the importance which crossborder cooperation between particular borderland areas has for local governments. He also referred to the importance of local government activity in this field offering so many opportunities.

The two-day conference was divided into individual plenary sessions. On the first day two plenary sessions were held. The first one was chaired by prof. Slawomir Partycki PhD Eng. and during this session, five speeches were delivered. In the first speech, "Subject and Experiences of Borderland Sociology in the Light of the Present-Day Challenges", prof. Zbigniew Kurcz from the University of Wroclaw addressed the history of borders and borderlands in the contemporary perspective. The speaker presented definitions and concepts related to the sociology of borderlands and their significance for contemporary society. The second speech "Borderlands as multicultural laboratories" was presented by prof. Andrzej Sadowski from the University of Białystok. He primarily emphasized that without multiculturalism one could not discuss borderlands. He also referred to aspects not only connected to borderlands, as a border between two states, but also as a place of contact between cultures. The issues of care networks were investigated by prof. Zofia Kawczyńska-Butrym (Maria Curie-Skłodowska University) and Dr Elżbieta Czapka (Maria Curie-Skłodowska University), dr Marek Butrym (University of Warmia and Mazury in Olsztyn) in their speech "Cross-border care networks". The next speaker, Prof. In his speech Tadeusz Popławski (Łomża State University of Applied Sciences in Łomża) raised the problems of borderlands from the point of view of management sciences. The last speech in this part of conference proceedings was about the role of borderlands in shaping attitudes towards emigration. This issue was taken up by Adam Kucharski PhD together
Konferencja obejmowała dwa dni obrad plenarnych. Pierwszy dzień obrad rozpoczął się od oficjalnego otwarcia. Przed rozpoczęciem obrad głos zabrała dr Joanna Marchel, prodziekan Wydziału Nauk o Zdrowiu i Nauk Społecznych. Oficjalnie przedstawiła ona przybyłych gości oraz nawiązała do historii miejsca tego spotkania, czyli Zespołu Dworsko-Parkowego w Roskoszy. Podkreślała, że cieszy się bardzo, że tak wielu uczestników pojawiło się z różnych stron kraju. W dalszej części spotkania głos zabrał prof. zw. dr hab. inż. Sławomir Partycki, przewodniczący Komitetu Naukowego, który podkreślał wyjątkowy charakter konferencji oraz wskazywał na istniejącego potrzeby związane z pogłębianiem zagadnień związanych z obszarami pogranicza. Wyjaśniał on, że to pogranicze, czyli powiat bialski oraz Biała Podlaska znajduje się w szczególnym miejscu bo jest jednocześnie pograniczem Unii Europejskiej w związku z tym nakładane są na nań dodatkowe obowiązki. Dlatego musi umieć nawiązać współpracę z sąsiadami z Białorusi i Ukrainy. Ma więc przed sobą specyficzne zadania, jako ten region. Obszar pogranicza to przede wszystkim powiat bialski, dlatego nie mogło zabraknąć przedstawicieli samorządu powiatowego. W imieniu starosty bialskiego głos zabrał Janusz Skolimowski, wicestarosta. Nawiązał do znaczenia, jakie dla samorządów ma współpraca transgraniczna pomiędzy poszczególnymi obszarami przygranicznymi. Nawiązał również do znaczenia działań samorządów w tej kwestii, jako obszarze wielu możliwości.

Dwudniowa konferencja podzielona były na poszczególne sesje plenarne. Pierwszego dnia odbyły się dwie sesje plenarne. Pierwszej z nich przewodniczył prof. zw. dr hab. inż. Sławomir Partycki, w jej trakcie wygłoszono pięć wystąpień. W pierwszym wystąpieniu „Przedmiot i doświadczenia socjologii pogranicza w świetle wyzwań współczesności" prof. zw. dr hab. Zbigniew Kurcz z Uniwersy tetu Wrocławskiego nawiązał do historii granic oraz pogranicza we współczesnej perspektywie. Prelegent przytoczył definicje oraz pojęcia związane z socjologią pogranicza oraz jej znaczeniu dla współczesnego społeczeństwa. Drugie wystapienie „Pogranicza jako laboratoria wielokulturowości" prezentował prof. zw. dr hab. Andrzej Sadowski z Uniwersytetu w Białymstoku. Podkreślał on przede wszystkim, że bez wielokulturowości nie można byłoby mówić o pograniczu. Nawiązywał również do aspektów związanych nie tylko z pograniczem, jako miejscem łączą się granice dwóch państw, ale również jako, miejsce stykania się kultur. Problematykę sieci opieki podjęli w swoim wystąpieniu „Transgraniczne sieci opieki” prof. zw. dr hab. Zofia Kawczyńska-Butrym (Uniwersytet Marii Curie-Skłodowskiej) oraz dr Elżbieta Czapka (Uniwersytet Marii Curie-Skłodowskiej) dr Marek Butrym (Uniwersytet Warmińsko-Mazurski w Olsztynie). Kolejny prelegent prof. nadzw. dr hab. Tadeusz Popławski (Państwowa Wyższa Szkoła Informatyki i Przedsiębiorczości w Łomży) poruszył w swoim wystąpieniu problemy pogranicza z punktu widzenia nauk o zarządzaniu. Ostatnie w tej grupie obrad wystąpienie dotyczyło roli pogranicza w kształtowaniu postaw wobec emigracji. Problematykę tę podjęli 
with Justyna Kuświk, M.Sc. from the University of Szczecin. This part of conference proceedings ended with a discussion.

The second part of the plenary session was chaired by prof. Zbigniew Kurcz. First speech „Space and information layout of cities divided by Polish-German border as an indicator of their crossborder character" was presented by Julita Makaro $\mathrm{PhD}$ (University of Wroclaw) She discussed her perceptions based on the practical and empirical research related to the information and spatial layout of cities on the Polish-German border. On the other hand, the legal aspects of cooperation between social organisations and public administration within the framework of EU programs supporting cross-border partnership were presented by Agnieszka Pieniążek $\mathrm{PhD}$ (Social Sciences Academy). In the next speech Elżbieta Opiłkowska PhD (University of Wrocław) described the current state of cross-border identity is presented on the example of the twin cities of Frankfurt Oder and Słubice. Her speech was rich in many practical examples related to the problems of the Polish-German border. This session was closed by the speech „The legal basis, determinants and practical examples of cross-border cooperation" prepared by prof. Mieczysław Adamowicz (Pope John II State School of Higher Education in Biała Podlaska) and Paweł Janulewicz PhD (University of Life Sciences in Lublin). The presenters drew attention to many legal issues influencing the problems of the eastern borderland. The debate ended with a discussion.

The proceedings of the second day of the conference also consisted of two parts. The first part of was chaired by the Chairperson: Julita Makaro PhD. The first speech was given by Dr Irena Szlachcic (University of Wrocław), who talked about the need for borders and their importance for the contemporary world and individual regions. The second speaker was Natalia Niedźwiecka-Iwańczak $\mathrm{PhD}$ (University of Wroclaw), who came forth with the presentation „Cross-border practices of Zgorzelec, Gubin and Słubice residents". In the next speech, the participants listened to a paper on security issues along the eastern border. This subject was taken up by Agnieszka Dawidziuk, MSc (Siedlce University of Natural Sciences and Humanities) in the paper „Crossborder security cooperation within the Euroregion Bug". In the further part of the session, the speech "National and Ethnic Conflicts in the Borderland Communities on the Example of Inhabitants of Podlaskie Voivodeship" was presented by Andrzej Nikitorowicz PhD (State Higher School of Vocational Education in Suwałki). The next presentation focused on the experiences of the inhabitants of cities located on the Polish-German border. The details were presented by Kamila Dolińska PhD (University of Wrocław) in the speech "On Social Boundaries in borderlands. German neighbours in the experience of the inhabitants living on the Polish side of the Divided Cities on the Polish-German Border". On the other hand, practical experiences of the eastern borderland were discussed in the next speech. The presentation entitled "Cultural Networks of the Cities and Region's dr Adam Kucharski wspólnie z mgr Justyną Kuświk z Uniwersytetu Szczecińskiego. Tę część obrad zakończono dyskusją.

Drugiej części obrad plenarnych przewodniczył prof. zw. dr hab. Zbigniew Kurcz. Pierwsze wystąpienie „Przestrzeń i szata informacyjna miast podzielonych granicą polsko-niemiecką jako wskaźnik ich transgraniczności" zaprezentowała dr hab. Julita Makaro (Uniwersytet Wrocławski). Omówiła ona praktyczne i oparte na empirycznych badań spostrzeżenia związane $\mathrm{z}$ szatą informacyjną oraz przestrzenią miast na granicy polsko - niemieckiej. Z kolei prawne aspekty współpracy organizacji społecznych i administracji publicznej w ramach programów UE wspierających transgraniczne partnerstwo zaprezentowała dr Agnieszka Pieniążek (Społeczna Akademia Nauk). W kolejnym wystąpieniu dr Elżbieta Opiłkowska (Uniwersytet Wrocławski), wskazała jak prezentuje się kreacja transgranicznej tożsamości na przykładzie miast bliźniaczych Frankfurtu n. Odrą i Słubic. Wystąpienie jej bogate było w wiele praktycznych przykładów związanych z problematyką pogranicza polsko-niemieckiego. Tę część obrad zamknęło wystąpienie „Podstawy prawne, determinanty i praktyczne przykłady współpracy transgranicznej" przygotowane przez prof. zw. dr hab. Mieczysława Adamowicza (Państwowa Szkoła Wyższa im. Papieża Jana Pawła II w Białej Podlaskiej) oraz dr Pawła Janulewicza (Uniwersytet Przyrodniczy w Lublinie). Prezentujący zwrócili uwagę na wiele kwestii prawnych regulujących problematykę pogranicza wschodniego. Obrady zakończono dyskusją.

Drugi dzień konferencji również obejmował dwie części obrad. Pierwszej części obrad przewodniczyła Obrady plenarne - przewodnicząca: dr hab. Julita Makaro. Pierwsze wystąpienie wygłosiła dr Irena Szlachcic (Uniwersytet Wrocławski), która mówiła o potrzebie granic, i ich znaczeniu dla współczesnego świata oraz poszczególnych regionów. Drugim prelegentem była dr Natalia Niedźwiecka-Iwańczak (Uniwersytet Wrocławski), która zaprezentowała wystąpienie „Praktyki transgraniczne mieszkańców Zgorzelca, Gubina i Słubic". W kolejnym wystąpieniu uczestniczy wysłuchali referatu dotyczącego problematyki bezpieczeństwa na granicy wschodniej. Tematykę tę w podjęła mgr Agnieszka Dawidziuk (Uniwersytet Przyrodniczo-Humanistyczny w Siedlcach) w referacie "Współpraca transgraniczna w zakresie bezpieczeństwa w granicach Euroregionu Bug". W dalszej części obrad z wystąpieniem „Konflikty narodowo-etniczne $\mathrm{w}$ społeczności pogranicza na przykładzie mieszkańców województwa podlaskiego" zaprezentował się dr Andrzej Nikitorowicz, (Państwowa Wyższa Szkoła Zawodowa w Suwałkach). Następne wystąpienie dotyczyło kwestii związanych z doświadczeniami mieszkańców miast znajdujących się na granicy Polski i Niemiec. Szczegóły prezentowała dr Kamila Dolińska (Uniwersytet Wrocławski) w wystąpieniu „O społecznych granicach na pograniczu. Niemieccy sąsiedzi w doświadczeniach mieszkańców polskich części miast podzielonych pogranicza polsko-niemieckiego". Z kolei praktyczne doświadczenia pogranicza wschodniego poruszano 
Partnership as a Chance for Local Development on the Example of the City of Lublin" was delivered by Ewa Sikora-Chołody PhD, representing the Regional Centre of Culture in Lublin. This part of the conference ended with a discussion.

The last part of the conference proceedings was chaired by Elżbieta Opiłowska PhD. The session began with the presentation "Cross-border Partnerships in Social Networks - the Example of Euroregions" prepared by prof. Sławomir Partycki, PhD, Eng. (Pope John Paul II State School of Higher Education in Biała Podlaska, John Paul II Catholic University of Lublin) and Dawid Błaszczak PhD (Pope John Paul II State School of Higher Education in Biała Podlaska). The next speaker raised the subject of cultural cooperation in the Association of the Euroregion Bug. This presentation was given by Agnieszka Drewniak PhD, representing the Centre for the Meeting of Cultures in Lublin. On the other hand, the issue of "Financing the Forms of Local Government Cooperation on the Example of the Association of the Euroregion Bug Local Governments" was presented by Agnieszka Cyburt PhD and Agnieszka Kuś PhD (Pope John Paul II State School of Higher Education in Biała Podlaska). Olga Filipiak PhD (Pope John Paul II State School of Higher Education in Biała Podlaska) spoke about the issue of consumption in border areas in the speech "Transformations in the Sphere of Consumption in Border Areas". The specific features of borderlands were also included in the presentation entitled "Civilizational Borderland as a Research Category" presented by Wiesław Romanowicz PhD (Pope John Paul II State School of Higher Education in Biała Podlaska). The last presentation "The case of the "borderland" in times of crises in the field of social science research" was presented by Magdalena El Ghamari PhD (University of Białystok). This part of the conference ended with a discussion. Then prof. Zbigniew Kurcz, PhD summed up the two-day conference and gathered the conclusions from the sessions.

During the conference, the participants also visited the Holy Mountain of Grabarka where they learned about its history and fortunes. They also went to see a horse farm in Janów Podlaski. They visited the museum in Romanów as well, where thanks to the courtesy of the management, they learnt about the life and work of J. I. Kraszewski.

The conference was devoted to borderlands and cross-border issues in various aspects, political, economic, cultural and social. The range of issues drew on something that already exists because there is a border division between countries. The purpose of the conference was to exchange experiences regarding two different borderland areas, i.e. the eastern and the western ones. The conference brought many essential experiences while giving opportunities for the development in the future.

The two-day conference "Borderlands in the Perspective of the Present-Day Challenges" gathered representatives of many academic centres from the whole country. Due to the presence of representatives of the University of Wrocław, the University of w kolejnym wystąpieniu. Referat „Kulturowe sieci partnerstwa miast i regionów szansą rozwoju lokalnego na przykładzie miasta Lublin" wygłosiła dr Ewa Sikora-Chołody reprezentująca Wojewódzki Ośrodek Kultury w Lublinie. Obrady zakończono dyskusją.

Ostatniej części obrad przewodniczyła dr Elżbieta Opiłowska. Obrady rozpoczęły się od wystąpienia „Partnerstwa transgraniczne w sieciach społecznych - przykład euroregionów" przygotowanego przez prof. zw. dr hab. inż. Sławomira Partyckiego (Państwowa Szkoła Wyższa im. Papieża Jana Pawła II w Białej Podlaskiej, Katolicki Uniwersytet Lubelski Jana Pawła II) oraz dr Dawida Błaszczaka (Państwowa Szkoła Wyższa im. Papieża Jana Pawła II w Białej Podlaskiej). Kolejny prelegent podjął tematykę współpracy kulturalnej Stowarzyszenia Euroregionu Bug. Wystąpienie to zaprezentowała dr Agnieszka Drewniak reprezentująca Centrum Spotkania Kultur w Lublinie. Z kolei problematykę „Finansowanie form współpracy samorządów lokalnych na przykładzie Stowarzyszenia Samorządów Euroregionu Bug" zaprezentowały dr Agnieszka Cyburt oraz dr Agnieszka Kuś (Państwowa Szkoła Wyższa im. Papieża Jana Pawła II w Białej Podlaskiej). O kwestii konsumpcji na terenach przygranicznych mówiła dr Olga Filipiak (Państwowa Szkoła Wyższa im. Papieża Jana Pawła II w Białej) w wystąpieniu „Przemiany w sferze konsumpcyjnej na obszarach przygranicznych". O specyficznych cechach pogranicza traktowało również wystąpienie „Pogranicze cywilizacyjne jako kategoria badawcza" zaprezentowane przez dr Wiesława Romanowicza (Państwowa Szkoła Wyższa im. Papieża Jana Pawła II w Białej Podlaskiej). Ostatnie wystąpienie „Casus „pogranicza” w dobie kryzysów w obszarze badań nauk o społeczeństwie" przedstawiła dr Magdalena El Ghamari (Uniwersytet w Białymstoku). Obrady zakończono dyskusją. Następnie prof. zw. dr hab. Zbigniew Kurcz dokonał podsumowania dwudniowej konferencji oraz zebrania wniosków z obrad.

W ramach konferencji uczestnicy odwiedzili również Świętą Górę Grabarkę, gdzie poznali jej historię oraz losy. Zwiedzili również stadninę koni w Janowie Podlaskim. Gościnnie odwiedzili także muzeum w Romanowie, gdzie dzięki uprzejmości dyrekcji poznali życie i twórczość J.I. Kraszewskiego.

Konferencja stanowiła okazję do dyskusji na temat pograniczy, transgraniczności $w$ różnych aspektach, zarówno politycznym, gospodarczym, kulturowym jak i społecznym. Tematyka wpisywała się w coś co już funkcjonuje, ponieważ istnieje graniczny podział państw. Celem konferencji była wymienia doświadczeń dotyczących dwóch różnych obszarów pograniczy, czyli wschodniego oraz zachodniego. Konferencja przyniosła wiele istotnych doświadczeń, jednocześnie dając możliwości rozwoju w bliższej i dalszej przyszłości.

Dwudniowa konferencja „Pogranicza w perspektywie wyzwań współczesności” zgromadziła wśród uczestników przedstawicieli wielu ośrodków akademickich w całym kraju. Dzięki obecności przedstawicieli Uniwersytetu Wrocławskiego, Uniwersytetu w Białymstoku, Uniwersytetu Marii Curie-Skłodowskiej w Lublinie, Uniwersytetu Warmiń- 
Białystok, Maria Curie-Skłodowska University in Lublin, the University of Warmia and Mazury in Olsztyn, Łomża State University of Applied Sciences, the University of Szczecin, the State Higher School of Vocational Education in Suwałki the meeting brought measurable effects in the form of in-depth discussion enriched with experiences of the inhabitants of various border areas. The two-day conference proceedings brought many valuable experiences to its participants. Undoubtedly, the reflections and the opportunity to exchange experiences and perceptions on various borderland areas allowed the participants to orientate their further cooperation.

Of the great importance was the Department of Sociology of the Pope John Paul II State School of Higher Education in Biała Podlaska, as the organiser of such a rich in experiences meeting. Great thanks are due to all participants for their attendance, speeches and participation in numerous discussions.
sko-Mazurskiego w Olsztynie, Państwowej Wyższej Szkoły Informatyki i Przedsiębiorczości w Łomży, Uniwersytetu Szczecińskiego, Państwowej Wyższej Szkoły Zawodowej w Suwałkach spotkanie przyniosło wymierne efekty w postaci pogłębionej dyskusji wzbogaconej doświadczeniami mieszkańców różnych obszarów pogranicza. Dwudniowe obrady przyniosły wiele cennych doświadczeń dla ich uczestników. Bez wątpienia rozważania oraz możliwość wymiany doświadczeń i spostrzeżeń na różnych pograniczach pozwoliła uczestnikom ukierunkowanie ich dalszej współpracy.

Szczególne znaczenie przypadło również Zakładowi Socjologii Państwowej Szkole Wyższej im. Papieża Jana Pawła II w Białej Podlaskiej, jako organizatorowi tak bogatego w doświadczenia spotkania. Podziękowania należą się również wszystkim uczestnikom za obecność, wygłoszone wystąpienia oraz udział w licznych dyskusjach. 